\title{
The Dutch observatory on employment and training
}

Citation for published version (APA):

Borghans, L., van Smoorenburg, M. S. M., \& de Grip, A. (1997). The Dutch observatory on employment and training. Researchcentrum voor Onderwijs en Arbeidsmarkt, Faculteit der Economische Wetenschappen. ROA Working Papers No. 2E https://doi.org/10.26481/umarow.199702E

Document status and date:

Published: 01/01/1997

DOI:

10.26481/umarow.199702E

Document Version:

Publisher's PDF, also known as Version of record

\section{Please check the document version of this publication:}

- A submitted manuscript is the version of the article upon submission and before peer-review. There can be important differences between the submitted version and the official published version of record.

People interested in the research are advised to contact the author for the final version of the publication, or visit the DOI to the publisher's website.

- The final author version and the galley proof are versions of the publication after peer review.

- The final published version features the final layout of the paper including the volume, issue and page numbers.

Link to publication

\footnotetext{
General rights rights.

- You may freely distribute the URL identifying the publication in the public portal. please follow below link for the End User Agreement:

www.umlib.nl/taverne-license

Take down policy

If you believe that this document breaches copyright please contact us at:

repository@maastrichtuniversity.nl

providing details and we will investigate your claim.
}

Copyright and moral rights for the publications made accessible in the public portal are retained by the authors and/or other copyright owners and it is a condition of accessing publications that users recognise and abide by the legal requirements associated with these

- Users may download and print one copy of any publication from the public portal for the purpose of private study or research.

- You may not further distribute the material or use it for any profit-making activity or commercial gain

If the publication is distributed under the terms of Article $25 \mathrm{fa}$ of the Dutch Copyright Act, indicated by the "Taverne" license above, 


\title{
The Dutch Observatory on Employment and Training
}

\author{
ROA-W-1997/2E
}

Andries de Grip, Michel van Smoorenburg, Lex Borghans

Paper presented at the MEANS-Seminar, European Commission DG V, Brussels, 5 March 1997

\section{Research Centre for Education and the Labour Market}

Faculty of Economics and Business Administration

Maastricht University

Maastricht, March 1997 
ISBN 90-5321-203-5

SEC97.028 


\section{Contents}

Page

1 Introduction $\quad 1$

2 Risks of losing employment $\quad 4$

2.1 Technological developments $\quad 4$

$\begin{array}{ll}2.2 \text { Labour market developments } & 6\end{array}$

3 Participation in training $\quad 11$

4 Risk profiles and potential target groups $\quad 14$

5 Training activities with good perspectives 17

6 Further development of WSO 19

$\begin{array}{ll}\text { References } & 20\end{array}$ 


\section{Introduction}

The combination of a shifting structure of employment and rapid technological developments often makes it very difficult for certain groups of workers to maintain their position in the labour market. What they face is economic obsolescence of their knowledge and skills. This is one of the reasons for the substantial decrease during the past few decades of the labour market participation rate of older age groups within the potential working population. However, other groups of workers may also face skill obsolescence for various reasons. It may be possible to fight this obsolescence of human capital - caused by the combined action of human, organisational, technological, and labour market developments - by means of a specific training policy, which prevents workers from being excluded from employment. Training policies aimed at the preservation of employment should therefore focus on two issues:

1. Which groups of workers run the risk of losing their jobs as a result of skills obsolescence?

2. What training activities would offer such workers better chances on the labour market?

These two research questions determine the framework of the Observatory on Employment and Training (WSO) developed by the Research Centre for Education and the Labour Market $(\mathrm{ROA})$. This Observatory attempts to generate on an annual basis an indicator system which is relevant for the anticipation of skills obsolescence due to, in particular, technological and labour market developments. The Observatory was set up by the Dutch Ministry of Social Affairs and Employment for the years 1996 to 1999 as part of the European Commission's programmes ESF-4 Training for the preservation of work and ADAPT. The task of the Observatory is to provide an on-going overview of the developments relevant for training policies, to gain timely insight in the training activities within sectors and companies, and to spot any gaps.

In its first report Werkgelegenheid en scholing 1996 (Employment and Training 1996) and the accompanying Statistical Appendix, a large number of indicators were presented in a systematic way on a relatively low level of aggregation, distinguishing (De Grip et al., 1997a, b, c):

- 7 firm-size classes;

- 13-20 economic sectors;

- 48 occupational segments (occasionally 93 occupational classes);

- 79 types of education.

It is not possible to summarise the approach developed without losing the greater part of the indicators presented in the Dutch report and its statistical appendix. However, to make the approach more clear we will illustrate this paper with some of the indicators generated.

\section{Skills obsolescence}

To give adequate answers to the two research questions formulated above, it is important to distinguish between the various types of skills obsolescence, as depreciation of human capital may take place in a number of ways. Firstly, depreciation of human capital may be caused by 
wear resulting from the natural ageing process, injuries, or illness. The second 'technical' type of skills obsolescence concerns atrophy. Atrophy is caused by the lack of, or insufficient, use of skills. This could be the result of unemployment, or of employees' working below their attained level of education. Also, as a result of specialisation certain knowledge and skills acquired during one's initial education may have become lost.

We can distinguish three more types of depreciation of human capital which relate to 'economic' obsolescence of skills. In the case of job-specific skills obsolescence, the required skills for particular jobs change with time. Existing knowledge and skills are no longer sufficient to perform a job properly. The second possibility is that the knowledge and skills of workers may be sufficient for their present jobs, but that the demand for this type of job is decreasing. This can be called skills obsolescence by market developments. Employment in an economic sector may shrink and the employment share of a particular occupation in an economic sector may decrease. A number of workers will then have to find different employment or work in a different economic sector. The third possibility concerns company-specific skills obsolescence. This may occur if external mobility is required because the creation of jobs in one company is accompanied with the destruction of jobs in another.

Table 1

Types of skills obsolescence and possible remedies

\begin{tabular}{|c|c|c|}
\hline Type of skills obsolescence & Depreciation of human capital by: & Possible remedy \\
\hline Wear & $\begin{array}{l}\text { Natural ageing process, } \\
\text { illness, or injury }\end{array}$ & $\begin{array}{l}\text { Refresher course or } \\
\text { retraining }\end{array}$ \\
\hline Atrophy & $\begin{array}{l}\text { Lack or insufficient use } \\
\text { of skills }\end{array}$ & Refresher course \\
\hline $\begin{array}{l}\text { Job-specific } \\
\text { skills obsolescence }\end{array}$ & $\begin{array}{l}\text { New skills requirements for } \\
\text { the job due to technological } \\
\text { developments }\end{array}$ & $\begin{array}{l}\text { (Substantial) } \\
\text { further training }\end{array}$ \\
\hline $\begin{array}{l}\text { Skills obsolescence } \\
\text { by market developments }\end{array}$ & $\begin{array}{l}\text { Shrinking employment in } \\
\text { occupation or economic sector }\end{array}$ & $\begin{array}{l}\text { Retraining } \\
\text { - } \text { same occupation, different } \\
\text { sector (reallocation) } \\
\text { - } \text { different occupation }\end{array}$ \\
\hline $\begin{array}{l}\text { Company-specific } \\
\text { skills obsolescence }\end{array}$ & External mobility & Further training or retraining \\
\hline
\end{tabular}

Table 1 contains a summary of these five types of skills obsolescence. It also shows which types of training could compensate for the skills obsolescence. In the case of depreciation of human capital as a result of mental wear and atrophy, refresher courses can be a suitable remedy. In the case of physical wear (e.g. as a result of injuries), the solution could be retraining. The term refresher courses is defined as a review of knowledge and skills which the individual has already acquired at some earlier stage. Further training, on the other hand, 
concerns the extension of existing knowledge or skills for the same job. If a particular occupation requires a higher level of education than in the past, substantial further training will be necessary. Further training can be used in particular as a remedy against job-specific skills obsolescence. Retraining is described as the acquisition of knowledge and skills for a different occupation or work in a different economic sector. Shrinking employment in a particular occupation or sector sometimes requires retraining. This may be retraining for a different occupation or retraining for the same occupation in a different sector.

Figure 1

Overview of the conceptual framework of the WSO

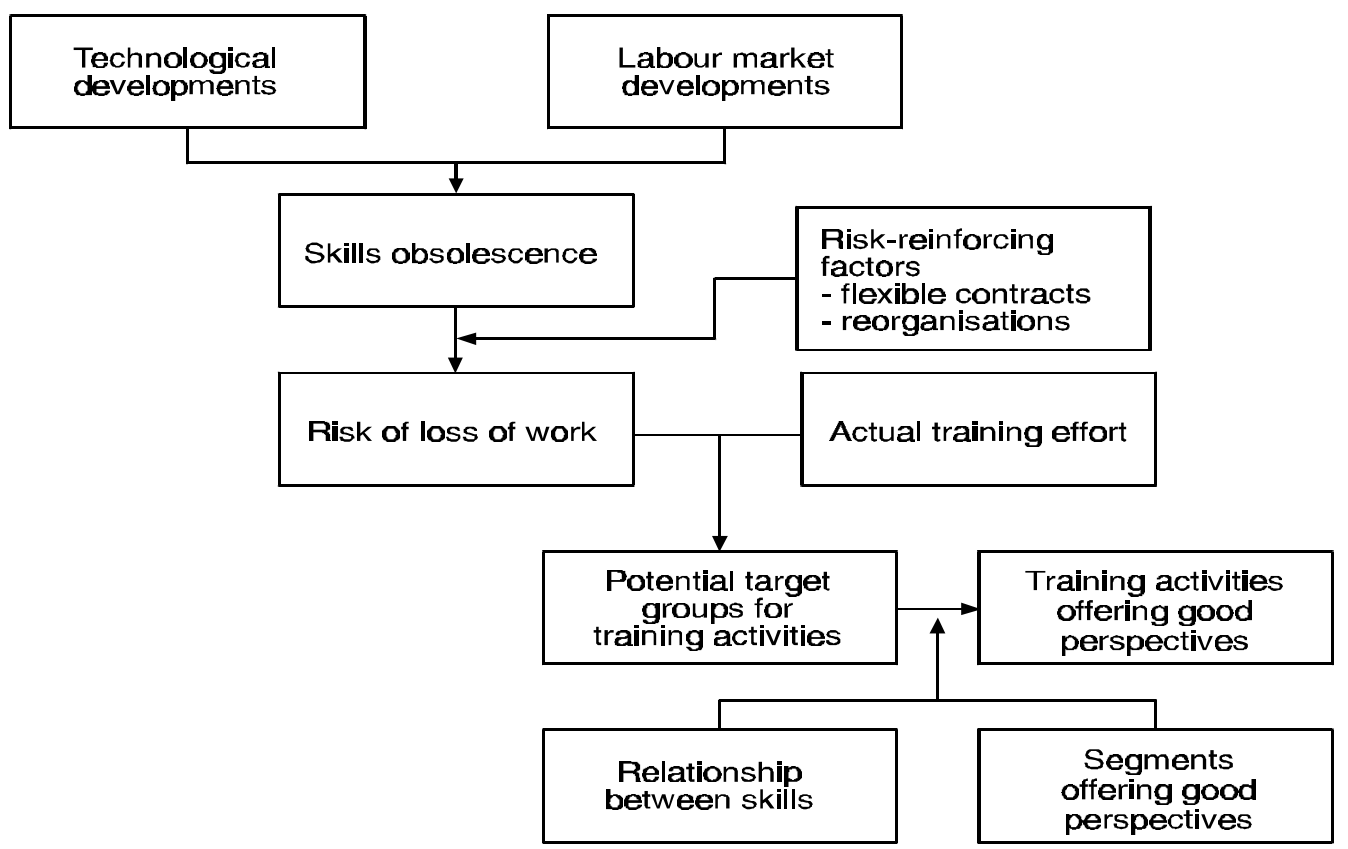

The required intensity of the training path depends on the extent of the relationship between the skills which a person has and the skills to be acquired. At this stage, this is implemented merely on the basis of similarity of educational backgrounds. Further training (extending knowledge and skills within the same occupation) usually requires less of a training effort than retraining for an entirely new occupation in a different economic sector.

There may also be a need for substantial further training, if the decrease of employment for workers with a particular educational level is largely the result of upgrading of the job level of occupations in which these workers are employed. It is then necessary to provide further training, for example for workers with only Lower/Preparatory Vocational Education (PVE), to raise their level to that of primary apprenticeship in order to enable them to perform their jobs properly. 
Figure 1 gives a general overview of the conceptual framework on the basis of which the WSO intends to generate the information necessary to be able to answer the two central questions. This diagram will be dealt with in detail in the following sections.

\section{Risks of losing employment}

In the first WSO report, the emphasis is on economic obsolescence because of technological and labour market developments. Two risk groups receive particular attention:

- workers facing rapid technological developments;

- workers facing unfavourable labour market developments.

There is also attention for the factors that reinforce the risk of losing employment as a result of skills obsolescence, including temporary labour contracts or persons working for a company which is undergoing reorganisation. In such cases there is a high risk of having to look for new work soon. In addition, employers then do not have an obvious interest in co-operating in training activities which may keep the knowledge and skills of employees up to date. The risk of losing employment will also be high for older employees facing job-specific skills obsolescence as a result of the upgrading of job requirements.

\subsection{Technological developments}

Table 2 gives an example of an indicator relating to the technological development per economic sector: the costs of automation per employee. In three economic sectors, the intensity of automation is low: agriculture and fisheries, health, veterinary services and social services, and construction far the highest costs of automation per employee, as expected, can be found in the sector computer service and information technology agencies. Because of the doubling of automation costs in banking during the period of 1989-'93, the latter can also be regarded as a sector with a very high intensity of automation.

In the Netherlands, little systematic data is available with regard to the impact of technological developments on particular jobs or occupations. An exception is a recent study by De Graaf et al. (1995). The latter calculated a combined information technology index which was based not only on the use of personal computers, but also on the use of modern facilities such as scanners, modems, computer conferencing, and electronic mail.

Table 2

Costs of automation per employee per economic sector, 1993

\begin{tabular}{lrl} 
Economic sector & $\begin{array}{r}\text { Costs of } \\
\text { automation } \\
\text { per employee }\end{array}$ & $\begin{array}{l}\text { Classification Trend } \\
1993\end{array}$ \\
1993 in $f$ & \\
\hline
\end{tabular}


Agriculture and fisheries

Health, veterinary and social services

Construction

Education

Plumbing and electrical fitting

Retail, catering, repair shops

Textile, clothing and leather industry

Other industry, mining

Food and beverage industry

Other business services

Metal industry and electrical industry

Paper and printing industry

Transport, storage and comm. companies

Other services

Wholesalers etc.

Public utilities

Oil, chem., rubber and plastic processing industry

Insurance

Banking

Computer service and IT agencies

$\begin{array}{rll}600 & \text { low } & \text { fluctuating } \\ 800 & \text { low } & \text { rising strongly } \\ 800 & \text { low } & \text { rising } \\ 1,200 & \text { average } & \text { rising strongly } \\ 1,300 & \text { average } & \text { fluctuating } \\ 1,400 & \text { average } & \text { rising } \\ 1,500 & \text { average } & \text { falling } \\ 2,000 & \text { average } & \text { falling strongly } \\ 3,200 & \text { average } & \text { rising strongly } \\ 3,200 & \text { average } & \text { falling } \\ 3,800 & \text { average } & \text { rising } \\ 4,000 & \text { average } & \text { rising } \\ 4,300 & \text { average } & \text { rising } \\ 4,500 & \text { average } & \text { rising } \\ 5,400 & \text { average } & \text { falling } \\ 7,600 & \text { average } & \text { constant } \\ 8,100 & \text { average } & \text { rising } \\ 16,600 & \text { high } & \text { fluctuating } \\ 30,000 & \text { very high } & \text { rising strongly } \\ 53,700 & \text { very high } & \text { rising }\end{array}$

4,300

constant

Source: CBS 1995b/ROA

Compared with other occupations, the fifteen occupational segments listed in Figure 2 make very frequent use of modern information technology. The figure shows that the occupational segments of higher administrative occupations and intermediate maritime and other water transport occupations have the highest scores in this information technology index. A similar analysis per type of education shows that in addition to the higher educated with a study in information science, it is in particular those who have completed an administrative/legal study - at Intermediate Vocational Education (IVE), Higher Vocational Education (HVE), or University Education (UE) level - who experience high levels of information technology. The studies of HVE, Business Administration and the studies of HVE and UE, Accountancy also yield high scores on this point.

Figure 2

Occupational segments with a high or very high information technology index 


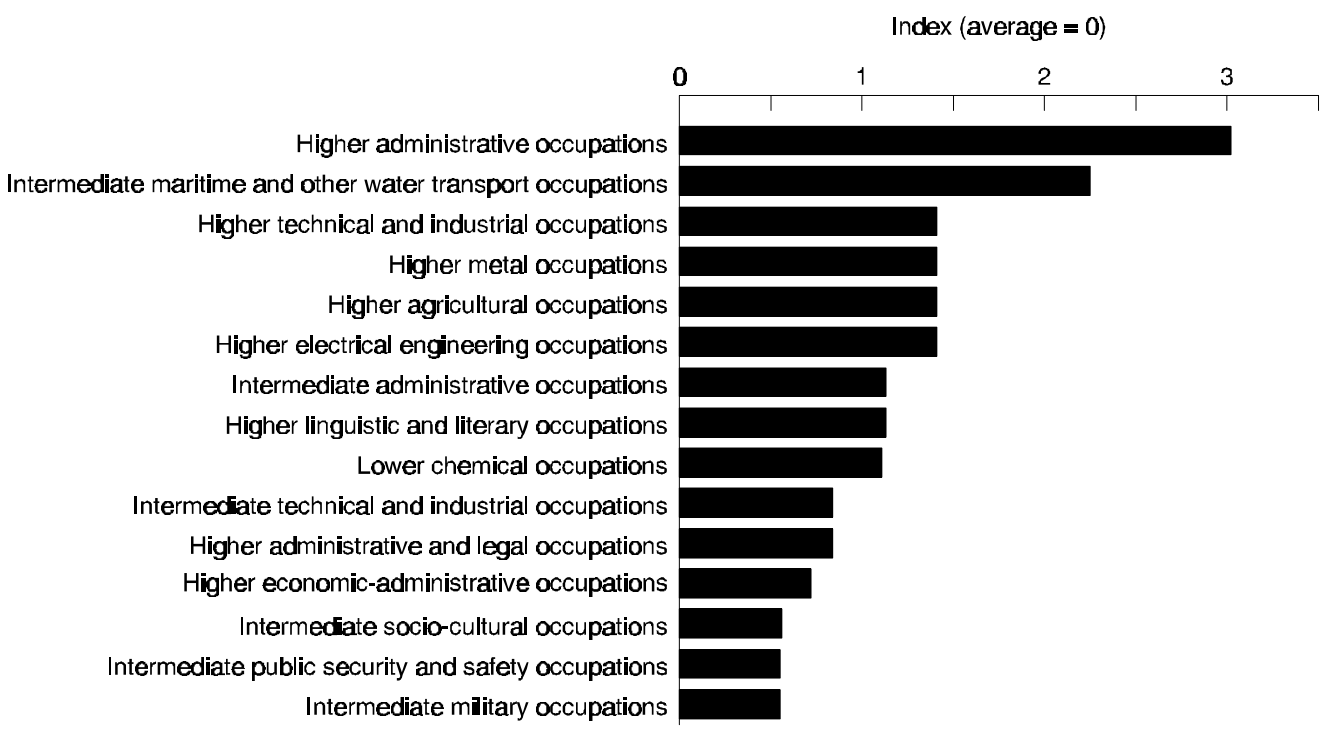

Source: De Graaf et al., (1995)

\subsection{Labour market developments}

To gain insight in the quantitative labour market developments which may lead to a training need, we will deal subsequently with the expected changes in employment per economic sector, occupational class, and type of education. For this purpose, we make use of the labour market forecasts of the ROA for the period of 1995-2000 (ROA, 1995a, b).

Table 3 provides an overview of the occupational segments where we may expect a high net rate of job losses in the period of 1995-2000. The net rate of job losses is expressed in absolute figures. Because of the shrinking employment within these occupational segments, retraining is usually the most suitable instrument to give the unemployed within these occupational segments a better labour market position. In the occupational segments of lower administrative occupations and lower agricultural occupations, we expect the greatest losses of jobs: in both occupational segments, around 30,000 jobs will be lost in a period of five years. In the occupational segment of lower building and engineering occupations, almost 15,000 jobs will be lost. It is striking that in particular the lower job levels face large employment decreases.

In relative terms, by far the greatest number of jobs will be lost in the occupational segment of intermediate military occupations, with a net loss of jobs of $28 \%$. In the lower agricultural occupations, lower textile occupations, and intermediate hotel and catering occupations, the loss of jobs is also considerable at 11 to $12 \%$. We also see that the employment decrease in intermediate administrative occupations is relatively small with an expected decrease of $3 \%$.

Table 3 
Occupational segments with the highest net loss of employment in the period of 1995-2000 (total number and average annual percentage)

\begin{tabular}{lrr}
\hline & \multicolumn{2}{c}{ Net loss of jobs } \\
& number & $\%$ \\
\hline & & 3 \\
Intermediate administrative occupations & 31,400 & 12 \\
Lower agricultural occupations & 29,700 & 7 \\
Lower building and engineering occupations & 14,600 & 3 \\
Lower hotel and catering occupations & 9,600 & 28 \\
Intermediate military occupations & 8,800 & 4 \\
Lower metal occupations & 8,000 & 5 \\
Lower wood and paper occupations & 7,100 & 12 \\
Lower textile occupations & 5,100 & 8 \\
Higher administrative and legal occupations & 4,700 & 11 \\
Intermediate hotel and catering occupations & 3,800 & \\
& & \\
\hline
\end{tabular}

Source: ROA

Table 4

Occupational segments with the greatest sectoral reallocation of employment in the period of 1995-2000 (total number and average annual percentage)

\begin{tabular}{lcc}
\hline & \multicolumn{2}{c}{ Reallocation } \\
& number & $\%$ \\
\hline & & \\
Intermediate administrative occupations & 40,600 & 4 \\
Lower metal occupations & 10,400 & 5 \\
Lower transport occupations & 8,900 & 7 \\
Intermediate commercial occupations & 8,000 & 3 \\
Lower administrative occupations & 4,700 & 10 \\
Higher socio-cultural occupations & 4,500 & 3 \\
Higher administrative and legal occupations & 4,000 & 7 \\
Lower wood and paper occupations & 4,000 & 3 \\
Intermediate electrical engineering occupations & 3,400 & 3 \\
Lower hotel and catering occupations & 2,700 & 1 \\
\hline
\end{tabular}

Source: ROA

In addition to the loss of employment in a particular occupational segment, a shift of employment in an occupational segment from one economic sector to another may also constitute a threat for the employment of those involved. Not all will have the necessary knowledge and skills to keep abreast of such developments. Table 4 shows the ten occupational segments with the highest sectoral reallocation of jobs. By far the largest reallocation of employment takes place within the occupational segment of intermediate administrative occupations; in the period of $1995-2000$, more than 40,000 jobs in these occupations will be sectorally reallocated.

Six occupational segments with a high degree or reallocation of employment - intermediate 
administrative occupations, lower metal occupations, higher administrative and legal occupations, lower wood and paper occupations, and lower hotel and catering occupations also belong to the occupational segments with the largest net loss of jobs. Apparently, in a number of cases a high decrease of employment coincides with a high sectoral reallocation of jobs. In the occupational segments of intermediate commercial occupations and higher socio-cultural occupations, on the other hand, the observed reallocation coincides with a very high net job increase.

Some of the occupational segments listed in tables 3 and 4 appear to represent a considerable share of the expected total loss of employment in the entire economy in the period of 19952000. We can see that the decrease of employment in the intermediate administrative occupations in the public sector is responsible for almost $20 \%$ of the total loss of jobs in 1995 2000.

\section{Developments in the demand per type of education}

Imminent loss of employment can also be analysed from the perspective of the educational backgrounds of workers. Table 5 gives an overview of the types of education for which a decreasing demand is expected for the period of 1995-2000. This may be due to a loss of jobs as a result of shrinking employment in the occupational segment or economic sector concerned, or due to substantial skills obsolescence for the occupations in which the workers with the educational background concerned are employed. In the latter case, there need not be a direct threat of loss of jobs.

The most conspicuous group is that of the unskilled workers (Primary Education) with an expected decrease of the demand of more than 66,000 jobs. Both in absolute and in relative terms, this is the type of education with the greatest decrease of demand. Other types which will experience a decreasing demand are in particular courses at PVE-level and Lower General Secondary Education (LGSE). We must add that a decreasing demand per type of education does not automatically mean that all the persons involved will lose their jobs. In a number of cases, unemployment may be avoided by accepting a job below one's own level. For workers with a PVE background, this is usually unskilled labour.

The decreasing demand for a particular type of education will not be the same in all occupational segments in which one is employed. The risk of unemployment for workers with a particular educational background will depend on the development of the demand of workers with the educational background concerned in the occupational segment in which one is employed. For example, the demand for workers with an LGSE level in intermediate military occupations is expected to decrease by $34 \%$ over a period of five years. This decrease of the demand is caused by the shrinking army.

Table 5

Types of education with the greatest absolute or relative decrease of demand 1995-2000 (total number and 


\begin{tabular}{lcc} 
Type of education & \multicolumn{2}{c}{$\begin{array}{c}\text { expansion demand } \\
\%\end{array}$} \\
& & \\
& & \\
& & \\
Primary education & $-66,300$ & -2.8 \\
Lower General Secondary Education & $-18,400$ & -0.9 \\
PVE, Construction trades & $-8,300$ & -1.2 \\
PVE, Mechanical trades & $-7,800$ & -1.2 \\
PVE, Agriculture & $-7,100$ & -1.9 \\
PVE, Community care, Hotel and Catering & $-6,400$ & -0.6 \\
PVE, Administration & $-3,800$ & -1.3 \\
PVE, Electrical trades & $-2,900$ & -1.0 \\
PVE, Automobile trades & $-2,700$ & -1.1 \\
IVE, Agriculture and natural environment & $-2,100$ & -0.3 \\
PVE, Textile and leather trades & $-1,100$ & -0.9 \\
PVE, Transport and harbour & -900 & -0.5 \\
\end{tabular}

\section{Source: ROA}

In an analysis of the upgrading of educational levels of workers in the Member States of the European Union, the changes of the average educational level of employment have been divided into an occupational and an educational effect (De Grip and Hoevenberg, 1996). The occupational effect concerns the shifts of the occupational structure of employment, whereas the educational effect indicates the changes of the average educational level within occupations. This gives us an indication of the risk of job-specific skills obsolescence. This analysis shows that in most European countries the educational effect is dominant. Given the occupation, the required educational level is increasing.

The modular structure of the forecasting model used (ROA, 1995a) enables us to expose the various components of the changes in labour demand by type of education. Table 6 shows the extent to which the demand for labour by level of education will change as a result of shifts in the industry structure of employment ('economic sector effect'), shifts in the occupational structure of the various economic sectors ('occupational effect'), shifts in the educational requirements for particular occupations, usually measured as 'upgrading' processes ('educational effect') and the 'crowding out' of types of education due to excess supply of related (higher) types of education ('substitution effect'). The table indicates that in particular the upgrading of skill requirements in the traditional occupational domain of unskilled or lowskilled workers is a major cause of decreasing employment in particular for unskilled (primary education) and low-skilled workers (PVE and LGSE).

Table 6

Components of the changes in employment levels per educational level (net effects), 1995-2000 


\begin{tabular}{|c|c|c|c|c|c|}
\hline & $\begin{array}{l}\text { economic } \\
\text { sector } \\
\text { effect } \\
\%\end{array}$ & $\begin{array}{c}\text { occupational } \\
\text { effect } \\
\text { \% }\end{array}$ & $\begin{array}{l}\text { educational } \\
\text { effect } \\
\text { (upgrading) } \\
\quad \%\end{array}$ & $\begin{array}{l}\text { substitution } \\
\text { effect } \\
\text { (crowding-out) } \\
\quad \%\end{array}$ & $\begin{array}{l}\text { total } \\
\%\end{array}$ \\
\hline $\begin{array}{l}\text { Primary Education } \\
\text { Lower General Secondary }\end{array}$ & 4,2 & $-4,2$ & $-13,1$ & $-1,7$ & $-14,8$ \\
\hline $\begin{array}{l}\text { Education and PVE } \\
\text { Higher General Secondary }\end{array}$ & 4,0 & $-3,1$ & $-5,4$ & $-3,2$ & $-7,7$ \\
\hline Education and IVE & 4,6 & $-1,0$ & 1,8 & $-0,7$ & 4,7 \\
\hline HVE & 3,7 & 5,8 & 4,9 & 3,8 & 18,2 \\
\hline University Education & 3,7 & 7,1 & 9,3 & 7,2 & 27,3 \\
\hline Total & 4,2 & 0 & 0 & 0 & 4,2 \\
\hline
\end{tabular}

Source: ROA

\section{Older workers}

Within the risk groups mentioned above, in particular the older workers probably run a higher risk of losing their jobs as a result of shortcomings in their educational background. On the one hand, the continuing upgrading may have rendered their initial education inadequate, whereas knowledge may also have been lost. For this reason, a comparison has been made between the educational background of workers of 50 years and older in a particular occupational class and the occupational class as a whole. This comparison shows that in many occupational classes, the unskilled (only Primary Education) are greatly overrepresented among the older workers. The largest differences can be found among operators and data-typists, transport and freight supervisors, production personnel textile industry, wood, paper and cardboard product workers, geriatric help and kindergarten staff, plumbers, drivers and conductors, and home nursing personnel.

\section{Flexible work}

As noted above, skills obsolescence is primarily a problem for those who do not have a permanent job, or have a great chance of losing such. In such cases, the risk of losing employment is reinforced. As a result of the skills obsolescence, it will be more difficult for such workers to find alternative employment. This problem is most urgent for those with flexible jobs.

Table 7 gives an overview of the percentages of flexible work for each economic sector. This table shows that in none of the economic sectors, the percentage or workers with flexible employment was higher than $10 \%$ in 1994-1995. A relatively high percentage or workers with flexible employment contracts can be found in the economic sectors of food and luxury food industry and the other commercial services. The percentage of workers with flexible employment is increasing rapidly in a number of economic sectors. This is the case in chemical industry, metal and electrical industry, energy, building, transport, storage and communication, non-commercial services and other commercial services. 
Table 7

Flexible work per economic sector, average 1994-1995

\begin{tabular}{lrll}
\hline Type of education & $\%$ & classification & trend 1993-'95 \\
\hline & & & \\
Agriculture and fisheries & 8 & average & constant \\
Food and beverage industry & 10 & high & constant \\
Other industries & 7 & average & rising \\
Chemical industry & 5 & low & rising strongly \\
Metal and electrical industries & 6 & average & rising strongly \\
Energy & 4 & low & rising strongly \\
Construction & 4 & low & rising strongly \\
Trade & 6 & average & constant \\
Transport, storage and communication & 10 & high & rising strongly \\
Other commercial services & 4 & low & rising strongly \\
Banking and insurance & 9 & average & rising strongly \\
Non-commercial services & 5 & low & rising \\
Civil service & & & \\
\end{tabular}

Source: CBS/ROA

The percentage of workers with flexible employment is highest among those with a Higher General Secondary Education (HGSE) diploma. No less than $16 \%$ of those who have such an educational background, have a flexible job. The educational types of $P V E$, Commerce, PVE, Community care, Hotel and Catering and LGSE also have a high percentage of workers in flexible employment: 12 to $13 \%$.

\section{Participation in training}

Against the risks of skills obsolescence, we find the efforts in the field of training. Figure 3 shows the development of training efforts in a particular economic sector, set off against the development of training efforts in all economic sectors. This figure shows that the training efforts in the construction sector have increased much more than one would expect on the basis of the general trend. In 1990 , for example, only $0.5 \%$ of the total cost of labour in this industry was spent on training, whereas this had already risen to $0.8 \%$ by 1993 . This means an annual growth of no less than $17 \%$. In spite of this rapid growth to catch up during the early nineties, the training effort in the building industry is still low. On the other hand, the construction sector has a relatively high number of apprenticeships. In commerce and hotel and catering, the training effort is not very high either. Moreover, there are no indications whatsoever that this economic sector is making any efforts to catch up. The sector of commerce and hotel and catering is even lagging behind the general trend. The costs of training as a percentage of the total labour costs decreased between 1990 and 1993 from $1.9 \%$ to $1.6 \%$. This is partly due to the fact that the number of courses per employee in this sector decreased. The average duration of training in both years is the same (seven days).

Figure 3 


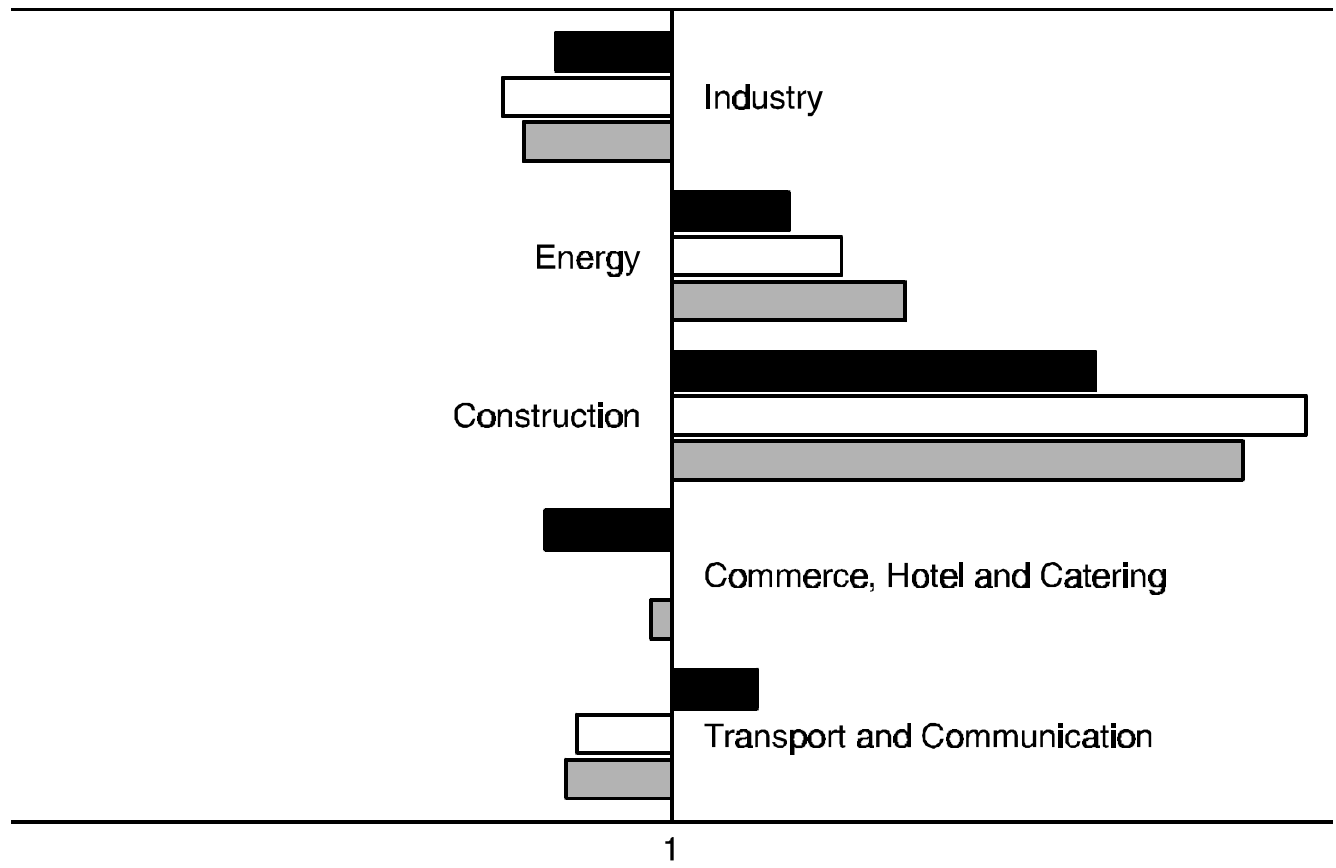

Number of courses per worker

Training costs as \% of labour costs

Training costs per workers

Source: CBS 1995a/ROA

The participation in training varies greatly per occupation. For example, two out of every three individuals employed in intermediate (sports) instructive occupations took a course between 1992 and '94, whereas in the lower textile occupations and the lower electrical engineering occupations, the participation in training was almost nil. As table 8 shows, the unskilled appear to take courses the least frequently. Among the unskilled, six per cent took a course in 1994, whereas among those with a university education, this was twenty per cent. This indicates that the participation in training is much higher among the higher educated.

Table 8

Participation in courses per level of education

Level of education

Participation in courses 1994

$\%$ 
Lower General Secondary Education $\quad 10$

Intermediate Vocational Education 13

Higher Vocational Education $\quad 13$

University Education $\quad 20$

Total

Source: OSA/ROA

Labour organisations need not necessarily train their own personnel in order to obtain more human capital. They may also recruit the required human capital on the labour market. In figure 4, we have listed twenty economic sectors with the average educational level of workers set off against the average training costs per worker. The economic sectors have subsequently been classified in four quadrants: make, buy, low-skill strategy and dual strategy (cf. Van Smoorenburg and Heijke, 1995). There are economic sectors which recruit personnel with a high educational level and also invest much in additional training of their personnel. By this dual strategy these sectors accumulate a great deal of human capital (dual strategy). Examples are the economic sectors of financial institutions and energy. There are also economic sectors with a low average educational level and hardly any training efforts (low-skill strategy). The latter make little use of human capital and make no effort to increase the human capital within the organization by means of training. Examples are the economic sectors of textile and clothing industry and other industry. We can also distinguish a quadrant in which workers have a low average education level, but considerable investments are being made in training. These economic sectors themselves create the required human capital (make). An example is the economic sector of transport and communication. The last group concerns the opposite situation, in which an average educational level is combined with a limited amount of additional training. Here, the required amount of human capital is simply bought on the external labour market (buy). This is the case in particular in the economic sector of commercial services, culture and other services.

Figure 4

The average training costs per worker, set off against the average educational level for economic sectors 


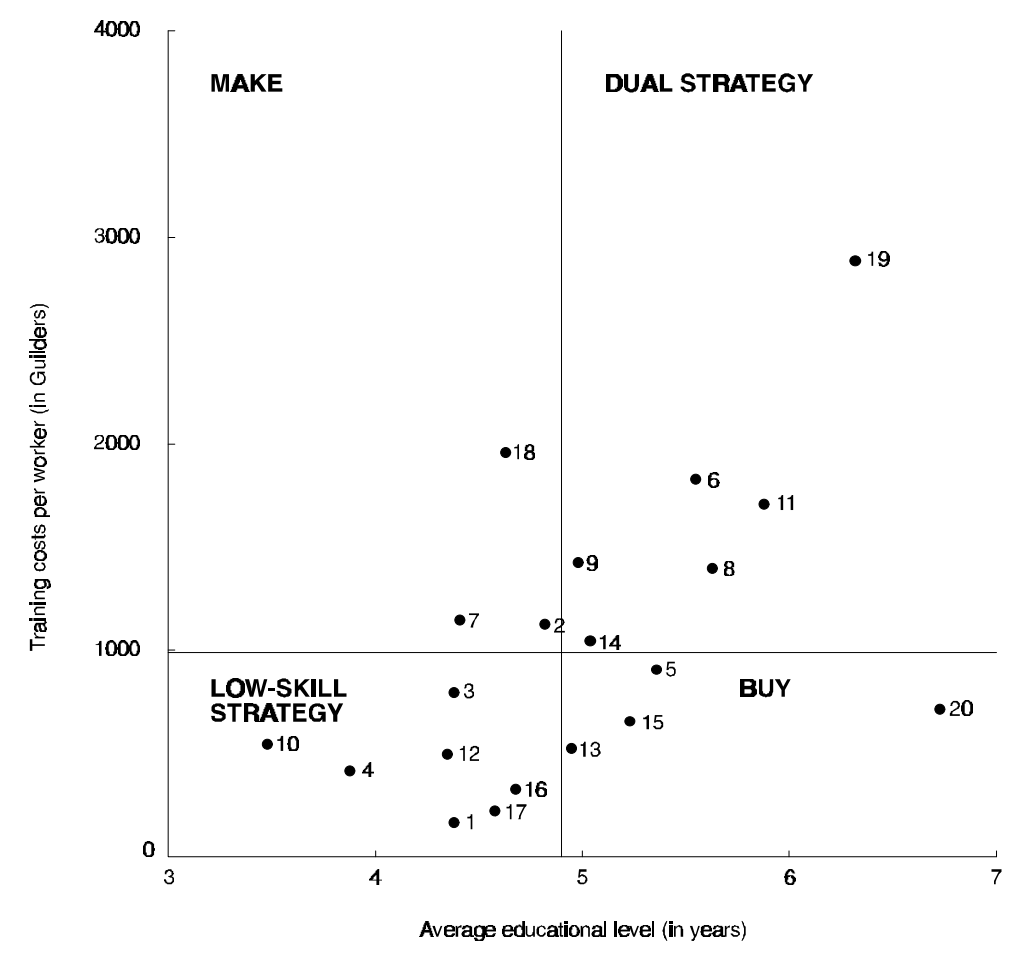

Bron: ROACBS 1995a/b

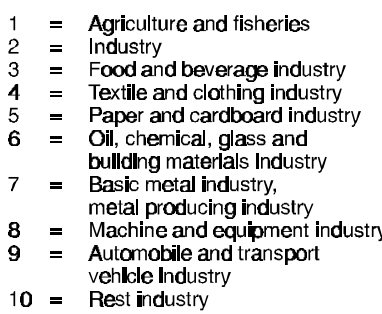

10 = Rest industry and other services

\section{Risk profiles and potential target groups}

\section{Risk profiles}

To map the risks of loss of work for each economic sector, occupation and type of education, so-called 'risk profiles' are presented. These risk profiles are created on the basis of three central perspectives: technological developments (Section 2.1), labour market developments (Section 2.2), and training efforts (Section 3). On the horizontal axis, the figures to the left show

Figure 5

The risk of loss of work for economic sectors: highest decrease of employment 

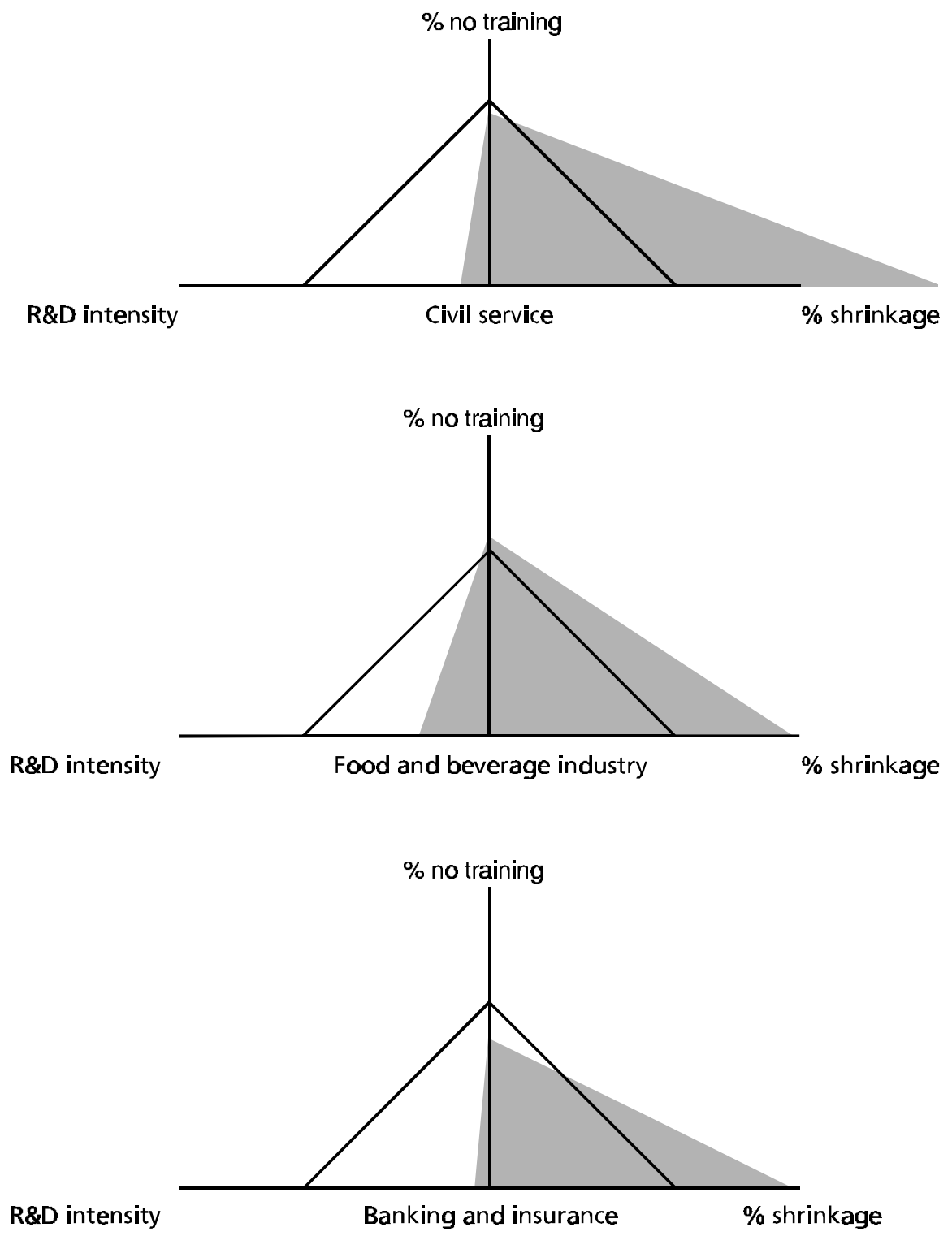

the technological developments. The latter are mapped on the basis of the intensity of Research and Development (R\&D). On the right, the figures show the volume of the predicted decrease of employment. On the vertical axis, an indication is given of the shortage of training on the basis of the percentage of workers which had not received any training between 1992 and 1994. The uninterrupted line indicates from when onwards we can see a high intensity of $R \& D$, a high decrease of employment, and a high shortage of training.

Table 9 
Economic sectors, occupational segments, types of education and target groups with a large or very large additional need for further training or retraining

Additional need for

Additional need for retraining further training or need for substantial further training

Economic sectors

Chemical industry

Other industry

Metal and electrical industry

Construction

Agriculture and fisheries

Other industry

Food and

beverage industry

Occupations

Lower textile occupations

Lower textile occupations

Higher technical and

industrial occupations

Higher administrative occupations

Lower electrical engineering

occupations

Higher commercial and administrative occupations

Higher administrative and

legal occupations

Lower food and beverage

occupations

Lower chemical occupations

Intermediate administrative

occupations

Higher medical and

paramedical occupations

Higher building and

engineering occupations

Types of education

HVE, Non-medical laboratory

HVE, Transport and harbour

PVE, Administration

PVE, Textile and leather trades

HVE, Business administration

UE, Arts

HVE, Mechanical engineering

Catering

IVE, Retail

Intermediate military occupations

Lower electrical engineering

occupations

Lower agricultural occupations

Higher administrative and legal

occupations

Lower administrative occupations

Lower building mat., glass and ceramic occupations

Lower food and beverage occupations Intermediate metal occupations

Lower wood and paper occupations

Primary education*

PVE, Agriculture

PVE, Textile and leather trades

PVE, Administration*

PVE, Food trades

PVE, Construction trades

PVE, Community care, Hotel and

PVE, Electrical trades*

Lower General Secondary Education*

PVE, Mechanical trades

PVE, Automobile trades

PVE, Utilities installation

PVE, Non-medical laboratory

Target groups

Workers with a flexible labour contract

The over-fifty (in particular in companies with a high intensity of $R \& D$ )

${ }^{*}$ A large share of workers with a substantial need for further training

The indicators have been chosen in such a way that, the larger the figure is, the larger the risk 
of loss of work is. Figure 5 gives an example of these risk profiles. The figure relates to three economic sectors with the highest decrease of employment. The civil service, the food and beverage industry and banking and insurance constitute the sectors with the highest decrease of employment in relative terms. In the case of the civil service, this is accompanied by a low intensity of R\&D, and hence the risk of loss of work in this sector is related to shrinking employment rather than to rapid technological developments. We must add, however, that in the public sector, the intensity of innovation, or the provision of new types of services, is high. The same is true for banking and insurance. In both the food and luxury food industry and the civil service, the decrease of employment is accompanied by a low participation in training, which increases the risk of loss of work.

\section{Potential target groups}

On the basis of a confrontation between, on the one hand, the major risk groups with respect to the loss of work, and on the other hand, the actual training efforts to prevent this risk, the major potential target groups for training policies have been traced. Table 9 gives an overview of the most important potential target groups, with detailed information as to their needs for further training and retraining. The additional need for further training here is based on the confrontation of indicators with respect to the technological development and actual participation in training. The additional need for retraining is based on the confrontation of the decrease of employment and reallocation with the actual training efforts.

\section{Training activities with good perspectives}

Lastly, information is given on the way in which these potential target groups may improve their labour market position by means of further training or retraining. The emphasis here is on retraining activities and substantial further training activities aimed at acquiring a higher level of education, which offer good chances of success. Table 10 shows for each occupational segment the occupational classes with good perspectives to which retraining could give access. The predicate of good perspectives is given to occupational classes with a high expected percentage of job opportunities - the sum of expansion and replacement demand (See ROA, 1995a, b). We here take into consideration the similarity in the educational background of the workers' occupations. Moreover, we restrict the switching opportunities to another occupation up to one job level above the current one.

For four occupational segments which were classified as a potential target group for training policies aimed at the preservation of work, the prospects are bad. For those involved, there are no opportunities for retraining for related occupations which offer good perspectives of findin employment. These concern the intermediate military occupations, lower agricultural occupations, lower food and beverage occupatios and the intermediate metal occupations. Workers in these occupational segments are therefore forced to retrain for occupations which are not related to their current ones. 
Table 10

Retraining opportunities with good perspectives for occupational segments which are potential target groups for training policies

Related occupational classes

with good perspectives

Lower textile occupations

Intermediate military occupations

Lower electrical engineering occupations

Lower agricultural occupations

Higher administrative and legal occupations

Lower administrative occupations

Lower build. mat., glass and ceramics occupations Lower building and engineering occupations

Lower food and luxury food occupations

Lower transport occupations

Intermediate metal occupations

Lower wood and paper occupations
Sales staff

Managers, supervisors and middle-management in building and industry

Technical draughtsmen

Sales staff

Policy staff and senior civil servants

Managers, supervisors and middle-management in building and industry

Shop managers, purchasers and representatives

Technical draughtsmen

Sales staff

Sales staff

Managers, supervisors and middle-management in building and industry

Technical draughtsmen

Sales staff

Technical draughtsmen

The other potential target groups do have opportunities for retraining for a related occupation with good labour market perspectives; workers in the lower electrical engineering occupations, for example, may retrain for jobs within the occupational class of managers, supervisors and middle-management in building and industry or to the occupation of technical draughtsmen. For the occupational segments of lower textile occupations, lower electrical engineering occupations, lower administrative occupations, lower building materials, glass and ceramics occupations and lower transport occupations, the retraining option for the occupational class of sales staff is mentioned.

\section{Training courses}

Table 11 gives an overview of training paths offering good perspectives for these potential target groups for training policies aimed at the preservation of employment. This was done by looking at related types of education with good labour market perspectives. To be able to give a realistic overview of the training opportunities for the potential target groups, we set a similar condition that one may be retrained to up to one educational level above the current level.

Here too, we must conclude that not all potential target groups have realistic retraining perspectives. For five types of education, there are no opportunities for retraining for related 
types of education offering good labour market perspectives. These concern the following types of education: PVE, Agriculture, PVE, Food trades, PVE, Construction trades, PVE, Electrical trades and PVE, Utilities installation. This implies that workers with any of these educational backgrounds will be forced to choose options which offer good perspectives but are unrelated to their present education.

For workers whose educational background is PVE, Administration or Lower General Secondary Education there are two potentially successful training paths. For both types of education, there are retraining opportunities to IVE, Legal and fiscal and IVE, Textile and leather technology. Of these, the IVE Legal and fiscal offers the best labour market perspective. Workers whose educational background is PVE, Automobile trades also have two good alternatives: PVE, Transport and harbour and IVE, Transport and harbour.

Table 11

Retraining opportunities with good perspectives for types of education which are potential target groups for training policies

Type of education

Related types of education

with good perspectives

Primary education

PVE, Agriculture

PVE, Textile and leather trades

PVE, Administration

PVE, Food trades

PVE, Construction trades

PVE, Community care, Hotel and Catering

PVE, Electrical trades

Lower General Secondary Education

PVE, Mechanical trades

PVE, Automobile trades

PVE, Utilities installation

HVE, Non-medical laboratory
PVE, Transport and harbour

IVE, Textile and leather technology

IVE, Legal and fiscal

IVE, Textile and leather technology

IVE, Textile and leather technology

IVE, Legal and fiscal

IVE, Textile and leather technology

PVE, Transport and harbour

PVE, Transport and harbour

IVE, Transport and harbour

HVE, Medical laboratory

\section{Further development of WSO}

The first report of the Observatory on Employment and training shows that it appears to be feasible to construct a coherent set of indicators which follows the line of the conceptual framework in a systematic way. Moreover, it enables us to give concrete signals with respect to the potential target groups for stimulating training activities and the occupational domains and educational qualifications for which these target groups should be trained. As mentioned in Section 2, the emphasis in the first version of the Observatory was on the economic obsolescence of skills due to technological and labour market developments, respectively. 
However, in 1997, attempts will be made to further develop the WSO. Particular attention will be paid to the following issues:

- generating indicators which provide insight in the risks of loss of employment resulting from wear caused by the natural ageing process, illness, etc.;

- investigating to what extent the need for further training as a result of technological developments must be related more explicitly to the job security of workers (flexible contracts, chances of redundancy as a result of market developments);

- improving of the insight in the nature of the required retraining, in terms of the required skills, for alternative occupations with good perspectives;

- improving the possibilities of generating relevant indicators from other sources of data.

\section{References}

CBS (1995b), Automatiseringsstatistieken, Particuliere sector 1993-1995, Computers en Communicatie 1993-1995, Centraal Bureau voor de Statistiek, Voorburg/Heerlen.

Graaf, P.M. de, E.J.C. Josten, P.T. van den Berg en R. Luijcks (1995), Informatietechnologie en kansen op werk, Tijdschrift voor Arbeidsvraagstukken, vol. 11, no. 1, pp. 7-20.

Grip, A. de en J. Hoevenberg (1996), Upgrading in the European Union, Research Centre for Education and the Labour Market, ROA-R-1996/3E, Maastricht.

Grip, A. de, M. van Smoorenburg, L. Borghans, N. Jonker (1997a), Werkgelegenheid en scholing 1996, Researchcentrum voor Onderwijs en Arbeidsmarkt, ROA-R-1997/1, Maastricht.

Grip, A. de, M. van Smoorenburg, L. Borghans, N. Jonker (1997b), Werkgelegenheid en scholing 1996, Statistische bijlage, Researchcentrum voor Onderwijs en Arbeidsmarkt, ROA-R-1997/1B, Maastricht.

Grip, A. de, M. van Smoorenburg, L. Borghans, N. Jonker (1997c), Methodiek werkgelegenheid en scholing 1996, Researchcentrum voor Onderwijs en Arbeidsmarkt, ROA-W-1997/1, Maastricht.

ROA (1995a), De arbeidsmarkt naar opleiding en beroep tot 2000, Researchcentrum voor Onderwijs en Arbeidsmarkt, ROA-R-1995/3, Maastricht.

ROA (1995b), De arbeidsmarkt naar opleiding en beroep tot 2000, Statistische bijlage, Researchcentrum voor Onderwijs en Arbeidsmarkt, ROA-R-1995/3B, Maastricht.

Smoorenburg, M.S.M. van en J.A.M. Heijke (1995), Training in bedrijven, Researchcentrum voor Onderwijs en Arbeidsmarkt, ROA-R-1995/5, Maastricht. 